\title{
DERAJAT KEASAMAN DAN ANGKA REDUKTASE SUSU KAMBING PERANAKAN ETTAWA PASTEURISASI DENGAN LAMA SIMPAN YANG BERBEDA PADA SUHU REFRIGERATOR $4^{\circ} \mathrm{C}$
}

\section{Degrees of Acidity and Reductase Scores of Pasteurized Ettawa Goat Milk with Different Storage Times at $4^{0} \mathrm{c}$ Refrigerator Temperature}

\author{
Egil Olsen, Arif Qisthon, Veronica Wanniatie, Ali Husni
}

Department of Animal Husbandry, Faculty of Agriculture, University of Lampung

Soemantri Brojonegoro No.1 Gedong Meneng Bandar Lampung 35145

E-mail : egil.olsen666@gmail.com

\begin{abstract}
This study aimed to determine the effect of storage time at $4^{\circ} \mathrm{C}$ refrigerator temperature on degrees of acidity and reductase score in pasteurized Ettawa goat milk and to determine the optimum storage time for pasteurized goat milk. This research was conducted in March--April 2020, at the Livestock Production Laboratory, Department of Animal Husbandry, Faculty of Agriculture, University of Lampung. The research material used was 6 liters of Ettawa Grade goat milk. This study used a completely randomized design, with 5 treatments and 4 replications, namely Pasteurized goat's milk stored for 0 days ( $\mathrm{P} 0)$, Pasteurized goat's milk was stored for 6 days (P1), Pasteurized goat's milk stored for 12 days (P2), Pasteurized goat's milk stored for 18 days (P3), and pasteurized goat milk stored for 24 days (P4). The variables observed were the degree of acidity, the amount of reductase, and the optimum storage time. The data obtained were then analyzed for variance / Analysis of Variance (ANOVA) at the 5\% significance level and continued with the Least Significant Difference (LSD) test. The results showed that pasteurized Ettawa goat's milk with a storage time of 24 days at $4^{\circ} \mathrm{C}$ refrigerator temperature had no significant effect on the degrees of acidity, but had a significant effect on the methylene blue reductase test. The conclusion of this research is that the storage time of Pasteurized goat's milk for 12 days at $4^{\circ} \mathrm{C}$ temperature is the optimum storage time to maintain the quality of milk with degrees of acidity of $7.5^{\circ} \mathrm{SH}$ and a reductase score for 8 hours.
\end{abstract}

Keywords: Reductase number, Titratable acidity, Pasteurization, Refrigerator, Goat milk

\begin{abstract}
ABSTRAK
Penelitian ini bertujuan untuk mengetahui pengaruh lama penyimpanan pada suhu refrigerator $4^{\circ} \mathrm{C}$ terhadap derajat keasaman dan angka reduktase pada susu kambing Pasteurisasi dan mengetahui lama penyimpanan optimum susu kambing Pasteurisasi. Penelitian ini dilaksanakan pada Maret-April 2020, bertempat di Laboratorium Produksi Ternak, Jurusan Peternakan, Fakultas Pertanian, Universitas Lampung. Materi penelitian menggunakan susu kambing Peranakan Ettawa sebanyak 6 liter. Penelitian ini menggunakan Rancangan Acak Lengkap, dengan 5 perlakuan dan 4 ulangan yaitu susu kambing Pasteurisasi disimpan selama 0 hari (P0), susu kambing Pasteurisasi disimpan selama 6 hari (P1), susu kambing Pasteurisasi disimpan selama 12 hari (P2), susu kambing Pasteurisasi disimpan selama 18 hari (P3), dan susu kambing Pasteurisasi disimpan selama 24 hari (P4). Peubah yang diamati adalah derajat keasaman, angka reduktase, dan lama penyimpanan optimum. Data yang diperoleh kemudian dianalisis sidik ragam/Analisis of Varian (ANOVA) pada taraf nyata 5\% dan dilanjutkan dengan uji Beda Nyata Terkecil (BNT). Hasil penelitian yaitu susu kambing Pasteurisasi dengan lama simpan selama 24 hari pada suhu refrigerator $4^{\circ} \mathrm{C}$ tidak berpengaruh nyata terhadap uji derajat keasaman, akan tetapi berpengaruh nyata terhadap uji reduktase methylene blue. Kesimpulan penelitian bahwa lama penyimpanan susu kambing Pasteurisasi selama 12 hari pada suhu $4^{\circ} \mathrm{C}$ adalah lama simpan optimum untuk mempertahan kualitas susu dengan derajat keasaman $7,5^{\circ} \mathrm{SH}$ dan angka reduktase selama 8 jam.
\end{abstract}

Kata kunci: Angka reduktase, Derajat keasaman, Pasteurisasi, Refrigerator, Susu kambing 


\section{PENDAHULUAN}

Kambing perah merupakan salah satu ternak penghasil susu. Susu merupakan sumber protein utama yang dihasilkan selain dari daging. Susu kambing memiliki keunggulan spesifik yang tidak dimiliki produk susu dari ternak lain seperti sapi perah. Salah satu keunggulan Susu kambing adalah mempunyai kandungan gizi yang sangat lengkap dan baik untuk kesehatan. Keunggulan lainnya dari susu kambing adalah tidak mengandung beta-lactoglobulin atau senyawa yang dapat memicu reaksi alergi seperti gangguan saluran pernapasan, efek merah pada kulit, dan gangguan percernaan (Parakasi, 2009).

Kambing yang dipelihara di Indonesia ada 2 tipe yaitu pedaging dan dwiguna (pedaging dan perah). Tipe kambing perah yaitu Ettawa, Peranakan Ettawa (PE), Sapera, Saanen, Alpin. Kambing PE sudah banyak diternakkan di Indonesia. Kambing perah dapat menghasilkan susu sekitar 0,25--0,50 liter per hari, namun apabila perawatannya baik dapat mencapai 1,50--2,00 liter per hari dengan masa laktasi selama 6--7 bulan (Sarwono, 2007; Budiarsana, 2011).

Permasalahan yang terjadi saat ini adalah susu kambing mudah rusak apabila disimpan dalam suhu ruang tanpa perlakuan, sehingga perlu dilakukan upaya untuk mencegah pertumbuhan bakteri pada susu agar lebih tahan lama sekaligus tetap mempertahankan kualitasnya. Untuk mengurangi resiko terjadinya kerusakan pada susu kambing maka selain susu diperah dari ambing yang bersih dan sehat serta lingkungan kandang yang bersih, penanganan pascapemerahan juga harus diperhatikan terutama pada penyimpanan. Salah satu cara untuk mengatasi masalah tersebut adalah dengan pemanasan susu dengan cara pasteurisasi.

Pasteurisasi merupakan salah satu cara pengolahan susu dengan cara pemanasan untuk mempertahankan mutu dan keamanan susu. Pasteurisasi pada susu dapat dilakukan dengan tiga cara yaitu Low Temperature Long Time (LTLT), High Temperature Short Time (HTST), dan Ultra High Temperature (UHT) (Sudarwanto, 2012). Cara pasteurisasi yang dilakukan juga berpengaruh terhadap kandungan gizi dan aroma produk pangan. Proses pasteurisasi susu dengan metode HTST dinilai lebih efektif, karena lebih sedikit menimbulkan kerusakan pada kandungan gizi dan karakteristik organoleptik pada susu, dibandingkan dengan LTLT.

Setelah proses pasteurisasi susu harus dilanjutkan dengan proses pendinginan untuk menghambat pertumbuhan dan perkembangan spora-spora bakteri. Susu pasteurisasi yang disimpan pada suhu yang tepat mempunyai daya simpan yang lebih baik dari pada yang tidak dipasteurisasi bila ditinjau dari derajat keasaman, $\mathrm{pH}$, dan angka reduktase. Susu pasteurisasi bila pada penyimpanan dingin dalam suatu tempat tertutup dan disimpan dalam lemari es yang bersuhu $\pm 4^{\circ} \mathrm{C}$ tidak rusak dalam waktu 7 hari (Umar et al, 2014). Penelitian lain mengidentifikasi bahwa susu yang dipasteurisasi dan disimpan pada penyimpanan dingin $\pm 5^{\circ} \mathrm{C}$ tidak rusak dalam waktu 12 hari (Oktavia et al, 2015). Tujuan penelitian ini adalah untuk mengetahui pengaruh lama simpan susu kambing pasteurisasi pada suhu refrigerator $4^{\circ} \mathrm{C}$ terhadap derajat keasaman, angka reduktase dan lama penyimpanan susu kambing pasteurisasi.

\section{MATERI DAN METODE}

Penelitian ini dilaksanakan pada MaretApril 2020 di Laboratorium Nutrisi dan Makanan Ternak, Jurusan Peternakan, Fakultas Pertanian, Universitas Lampung.

\section{Materi}

Bahan-bahan yang digunakan pada penelitian ini yaitu, susu kambing Peranakan Ettawa (PE) sebanyak 6 liter, methylene blue, phenolphtalin, cobalt-sulfat, dan larutan $\mathrm{NaOH}$ $0,25 \mathrm{~N}$. Peralatan yang digunakan dalam penelitian ini diantaranya yaitu kotak pendingin, buret, pipet tetes, gelas Beaker, gelas ukur, tabung reaksi, rak tabung reaksi, sumbat karet, inkubator, thermometer air, termometer kopel digital, panci, refrigerator, kompor, botol kaca, botol plastik, dan botol duran.

\section{Metode}

\section{Rancangan Percobaan}

Penelitian ini menggunakan Rancangan Acak Lengkap (RAL) dengan 5 perlakuan lama penyimpanan dan 4 ulangan, yaitu :

P0 : Susu kambing pasteurisasi disimpan selama 0 hari

P1 : Susu kambing pasteurisasi disimpan selama 6 hari

P2 : Susu kambing pasteurisasi disimpan selama 12 hari

P3 : Susu kambing pasteurisasi disimpan selama 18 hari

P4 : Susu kambing pasteurisasi disimpan selama 24 hari

\section{Analisis data}

Data yang diperoleh dianalisis sidik ragam/Analysis of Variance (ANOVA) pada taraf nyata $5 \%$, apabila dari hasil analisis ragam menunjukkan hasil yang nyata maka dilanjutkan dengan uji Beda Nyata Terkecil (BNT). 


\section{Peubah Penelitian}

Peubah yang diamati dalam penelitian ini adalah derajat keasaman dan angka reduktase

\section{Pelaksanaan Penelitian}

\section{Koleksi Sampel}

Sampel susu diambil sebanyak 6 liter dari peternak dan ditempatkan di dalam wadah plastic, lalu dibawa ke laboratorium dalam kondisi dingin.

\section{Perlakuan Pada Sampel}

Susu dipasteurisasi menggunakan metode HTST dengan suhu $72^{\circ} \mathrm{C}$ selama 15 detik. Susu yang sudah dipasteurisasikan disimpan dalam refrigerator dengan suhu $4^{\circ} \mathrm{C}$ dengan lama simpan sesuai dengan perlakuan. Mengamati suhu pada termometer kopel digital yang diletakkan di refrigerator agar suhu tetap berada pada suhu $4^{\circ} \mathrm{C}$.

\section{Prosedur}

\section{a. Uji derajat keasaman}

Pengujian derajat keasaman susu dilakukan dengan menggunakan metode Sudarwanto (2012). Membuat larutan phenolphtalin 2\% dengan cara $2 \mathrm{~g}$ phenolphtalin dilarutkan dalam etanol 96\% sampai volume $100 \mathrm{ml}$. Memasukkan $1 \mathrm{ml}$ larutan phenolphtalin $2 \%$ ke dalam $25 \mathrm{ml}$ contoh susu dalam beaker glass. Menitrasi dengan larutan $\mathrm{NaOH} 0,25 \mathrm{~N}$, sambil terus dikocok sampai terbentuk warna yang sesuai yaitu warna merah muda, dengan lama titrasi tidak lebih dari 30 detik. Mengitung jumlah $\mathrm{NaOH}$ yang terpakai (ml) dengan rumus:

$$
\text { Derajat asam }\left({ }^{\circ} \mathrm{SH}\right)=\frac{a \times 100}{b}
$$

Keterangan:

$\mathrm{a}=$ jumlah $\mathrm{NaOH} 0,25 \mathrm{~N}$ yang terpakai

$\mathrm{b}=$ volume contoh susu yang digunakan $(\mathrm{ml})$

\section{b. Uji reduktase methylene blue}

Pengujian angka reduktase susu dilakukan dengan menggunakan metode Sudarwanto (2012). Membuat larutan methylene blue dengan cara memasukkan 0,010 g methylene blue ke dalam erlemeyer steril, lalu ditambah aquades steril sampai dengan $100 \mathrm{ml}$ larutan. Mencampur larutan dengan baik dan simpan pada suhu rendah dan terlindungi dari cahaya. Memasukkan 0,5 ml larutan methylene blue 0,01\% ke dalam tabung reduktase. Menambahkan sampel susu sebanyak 20 $\mathrm{ml}$. Menutup tabung tersebut dengan sumbat karet, lalu campurkan sehingga warna biru merata, dengan cara membolak-balik (kira-kira 3 kali). Memasukkan tabung ke dalam inkubator pada suhu $37^{\circ} \mathrm{C}$. Memeriksa perlakuan setiap setengah jam untuk mengetahui perubahan warna, dilakukan selama 8 jam. Angka reduktase ditentukan berdasarkan waktu (jam) terjadinya perubahan warna methylene blue menjadi tidak bewarna. Standar Nasional Indonesia untuk angka reduktase susu Pasteurisasi yaitu sebesar 8 jam.

\section{HASIL DAN PEMBAHASAN}

\section{A. Derajat keasaman susu kambing pasteurisasi}

Rata-rata nilai derajat keasaman susu kambing Peranakan Ettawa pasteurisasi yang disimpan selama $0,6,12,18$ dan 24 hari di dalam refrigerator dapat dilihat pada Tabel 1 . Hasil analisis ragam menunjukkan bahwa susu kambing pasteurisasi dengan perlakuan lama penyimpanan berbeda selama $0,612,18$, dan 24 hari pada suhu $4^{\circ} \mathrm{C}$ tidak berpengaruh nyata $(\mathrm{P}>0,05)$ terhadap nilai derajat keasaman susu.

Tabel 1. Hasil uji derajat keasaman $\left({ }^{0} \mathrm{SH}\right)$ susu kambing pasteurisasi pada lama simpan yang berbeda

\begin{tabular}{cccccc}
\hline \multirow{2}{*}{ Ulangan } & \multicolumn{5}{c}{ Perlakuan } \\
\cline { 2 - 6 } & P0 & P1 & P2 & P3 & P4 \\
\hline 1 & 9,8 & 9,8 & 7,6 & 8,4 & 10,4 \\
2 & 8,4 & 11 & 8,2 & 9 & 10,8 \\
3 & 10,4 & 8 & 6 & 12,4 & 9,4 \\
4 & 9,5 & 9 & 8,4 & 8,4 & 9 \\
\hline Jumlah & 38,1 & 37,8 & 50 & 38,2 & 39,6 \\
\hline Rata-rata & 9,52 & 9,4 & 7,5 & 9,55 & 9,90 \\
\hline Keterangan : & \multicolumn{5}{c}{} \\
P0 : Susu kambing pasteurisasi disimpan selama 0 hari \\
P1 : Susu kambing pasteurisasi disimpan selama 6 hari \\
P2 : Susu kambing pasteurisasi disimpan selama 12 hari \\
P3 : Susu kambing pasteurisasi disimpan selama 18 hari \\
P4 : Susu kambing pasteurisasi disimpan selama 24 hari
\end{tabular}

Susu kambing pasteurisasi yang disimpan hingga 24 hari memiliki rata-rata nilai derajat keasasam lebih dari $7,0^{\circ} \mathrm{SH}$. Menurut Nababan (2015), tingginya nilai derajat keasaman diperkirakan karena terjadinya kontaminasi dari luar dan kondisi susu itu sendiri serta pengaruh lingkungan. Kontaminasi dari luar dapat disebabkan oleh proses pemerahan tidak higienis yaitu tangan pemerah dan ambing ternak yang tidak dicuci terlebih dahulu dan dibasuh dengan air hangat, serta wadah penampungan air susu yang tidak steril karena memakai botol bekas.

Tingginya nilai derajat keasaman diperkirakan akibat adanya bakteri pembusuk seperti Micrococcus sp., Pseudomonas sp., dan Bacillus sp. akan menguraikan protein menjadi asam amino dan merombak lemak dengan lipase sehingga susu menjadi asam dan berlendir (Suwito, 
2010). Hubungan yang erat antara kadar protein dengan derajat keasaman dapat terjadi karena kenaikan kadar protein susu, sehingga derajat asam naik di atas 7,6 ${ }^{\circ} \mathrm{SH}$ Tingginya nilai derajat keasaman pada susu kambing dapat diakibatkan oleh proses pemanasan, yaitu dengan terjadinya peristiwa beralihnya kalsium fosfat terlarut dalam larutan kolodial menyebabkan peningkatan derajat asam. Pemanasan yang tinggi menimbulkan peningkatan keasaman yang disebabkan kerusakan laktosa (Sudarwanto, 2012).

\section{B. Angka reduktase susu kambing pasteurisasi}

Uji reduktase susu kambing pasteurisasi yang disimpan selama $0,612,18$, dan 24 hari dalam refrigerator pada suhu $4^{\circ} \mathrm{C}$ dapat dilihat pada Tabel 2. Hasil analisis ragam menunjukkan bahwa lama penyimpanan berpengaruh nyata $(\mathrm{P} \leq 0,05)$ terhadap angka reduktase susu kambing pasteurisasi.

Tabel 2 menunjukkan bahwa selama penyimpanan $\leq 12$ hari dalam refrigerator waktu reduktase terjadi pada jam ke 8 . Susu kambing pasteurisasi dengan masa penyimpanan 18 hingga 24 hari waktu reduktase terjadi pada jam ke 7, sehingga semakin lama penyimpanan maka semakin cepat waktu reduktase atau waktu warna biru dari methylene blue berubah menjadi warna putih (Puspitarini, 2015). Menurut Puspitarini (2015), mikroba yang tumbuh di dalam susu kambing pasteurisasi semakin banyak maka mikroba akan memanfaatkan oksigen sehingga mereduksi warna methylene blue dan semakin cepat waktu reduksi perubahan warna biru dari methylene blue menjadi putih.

Tabel 2. Hasil uji angka reduktase susu kambing pasteurisasi pada lama simpan yang berbeda

\begin{tabular}{cccccc}
\hline \multirow{2}{*}{ Ulangan } & \multicolumn{5}{c}{ Perlakuan } \\
\cline { 2 - 6 } & P0 & P1 & P2 & P3 & P4 \\
\hline 1 & 8 & 8 & 8 & 7,5 & 6,5 \\
2 & 7,5 & 8 & 8 & 6 & 7,5 \\
3 & 6,5 & 8 & 8 & 7,5 & 7,5 \\
4 & 6 & 8 & 8 & 7 & 6,5 \\
\hline Jumlah & 28 & 32 & 32 & 28 & 28 \\
\hline Rata-rata & $7,00^{\mathrm{a}}$ & $8,00^{\mathrm{b}}$ & $8,00^{\mathrm{b}}$ & $7,00^{\mathrm{a}}$ & $7,00^{\mathrm{a}}$ \\
\hline
\end{tabular}

Keterangan : Nilai dengan huruf superscript yang berbeda pada baris yang sama menunjukkan berbeda nyata $(\mathrm{P}<0,05)$. P0 : Susu kambing pasteurisasi disimpan selama 0 hari P1 : Susu kambing pasteurisasi disimpan selama 6 hari P2 : Susu kambing pasteurisasi disimpan selama 12 hari P3 : Susu kambing pasteurisasi disimpan selama 18 hari P4 : Susu kambing pasteurisasi disimpan selama 24 hari

Susu kambing pasteurisasi dengan perlakuan tanpa lama simpan (P0), angka reduktase terrendah yaitu terjadi pada jam ke 6. Hal ini diduga, karena proses pasteurisasi hanya dapat menghancurkan 90--99\% bakteri dari total bakteri yang berada di dalam susu (Setya, 2012). Setelah proses pasteurisasi masih terdapat bakteri yang dapat bertahan, sehingga pada saat dilakukannya uji angka reduktase susu mengalami perubahan warna biru yang lebih cepat.

Susu kambing dengan perlakuan penyimpanan 6 dan 12 hari pada uji angka reduktase terjadi pada jam ke 8. Menurut Susilorini dan Sawitri (2006), bahwa asumsi jumlah mikroba pada waktu reduktase lebih dari 8 jam berkisar $<500.000$ $\mathrm{cfu} / \mathrm{ml}$. Susu yang disimpan selama 6 sampai dengan 12 hari masih dalam kualitas yang baik, hal ini disebabkan susu disimpan dalam refrigerator dengan suhu $4^{\circ} \mathrm{C}$. Hal ini terjadi karena bakteri termodurik tidak dapat bertahan pada suhu $4^{\circ} \mathrm{C}$. Bakteri termodurik tidak tahan pada suhu dingin, sehingga mati pada saat peyimpanan dingin (Kristanti et al., 2015). Hampir semua bakteri termodurik yang terdapat dalam susu pasteurisasi yang disimpan pada suhu refrigerator akan terhambat pertumbuhannya dan umumnya tersaingi oleh spesies-spesies psikrotrofik gram negatif yang masuk sebagai pencemar setelah proses pasteurisasi (Sudarwanto, 2012).

Susu yang dipasteurisasikan dan disimpan pada penyimpanan dingin $\pm 4^{\circ} \mathrm{C}$ tidak rusak dalam waktu 12 hari (Murniah, 2005). Rofi'i (2009) menyatakan bahwa penyimpanan susu pada suhu rendah $\left(<10^{\circ} \mathrm{C}\right)$ lebih efektif dalam menghambat pertumbuhan bakteri dan aktivitas enzimatisnya dibandingkan dengan penyimpanan pada suhu ruangan. Pendinginan susu bertujuan untuk menahan agar mikroba perusak susu jangan sampai berkembang, sehingga susu tidak mengalami kerusakan dalam waktu yang relatif singkat (Ismanto et al, 2013).

Susu kambing pasteurisasi dengan lama simpan 18 dan 24 hari memiliki rata-rata waktu reduktase yang lebih cepat yaitu 7 jam. Susu dengan angka reduktase 7 jam masih dikatakan susu dengan kualitas baik. Menurut Hadiwiyoto (1994), waktu reduktase susu yang normal adalah dua sampai lima jam. Semakin lama terjadi perubahan warna methylene blue pada susu segar menjadi putih kembali menunjukkan bahwa jumlah bakteri dalam susu semakin sedikit. Menurut Sudarwanto (2012), beberapa bakteri termodurik tertentu khususnya Bacillus spp. yang bersifat psikrotrofik dan membentuk spora, berjumlah tinggi sehingga menyebabkan pembusukan (sweat-curdling) pada susu pasteurisasi yang disimpan pada suhu rendah. Bakteri psikrotrofik mempunyai suhu pertumbuhan di bawah $20^{\circ} \mathrm{C}$ (Prescott, 2005).

Susu kambing pasteurisasi dengan lama simpan 18 hingga 24 hari jumlah mikroba 
diperkirakan mencapai $2 \times 10^{6} \mathrm{cfu} / \mathrm{ml}$ (Puspitarini et al., 2015). Lamanya waktu perubahan warna dari biru menjadi putih ini sebagai dasar penentuan perkiraan jumlah bakteri (Umar, 2014). Berubahnya warna biru metilen pada periode yang panjang atau pendek, berkaitan dengan jumlah bakteri (Sari, et al, 2013). Menurut Susilorini dan Sawitri (2006), jika waktu reduksi susu berada pada kisaran 6 hingga 8 jam bahwa perkiraan jumlah bakteri sekitar $1 \times 10^{6}--4 \times 10^{6} \mathrm{cfu} / \mathrm{ml}$ atau dengan mutu susu yang cukup baik. Didukung oleh Soeparno et al, (2001) bahwa semakin banyak mikroba yang terdapat di dalam susu maka semakin banyak senyawa pereduksi yang dihasilkan mikroba untuk mengubah warna methylene blue menjadi putih sehingga waktu perubahan warna menjadi lebih cepat.

\section{SIMPULAN}

Simpulan dari penelitian ini yaitu lama penyimpanan susu kambing pasteuriasi yang berbeda pada suhu refrigerator $4^{\circ} \mathrm{C}$ mempengaruhi angka reduktase dan tidak berpengaruh terhadap derajat keasaman. Berdasarkan uji lanjut BNT didapatkan hasil bahwa pada uji reduktase methylene blue dengan perlakuan lama simpan 6 dan 12 hari berbeda nyata $(\mathrm{P}<0,05)$ jika dibandingkan dengan susu kambing pasteurisasi perlakuan lama simpan 0 hari, 18 hari, dan 24 hari.

\section{DAFTAR PUSTAKA}

Krsitianti, N. D., Rosyidi, D., Radiati, L. E. dan Purwadi. 2015. Phylogenetic Tree and Heat Resistance of Thermoduric Bacteria Isolated from Pasteurization Milk in Indonesia. International Journal of Biosciences. 6(11): 87--98.

Budiarsana, I. G. M. 2011. Produktivitas dan Nilai Ekonomi Usaha Ternak Kambing Perah Skala Kecil. Bogor.

Ismanto, T., S. Utami, dan H. A. Suratim. 2013. Pengaruh lama penyimpanan dalam refrigerator terhadap berat jenis dan viskositas susu kambing pasteurisasi. Jurnal Ilmiah Peternakan. 1(1): 69--78.

Prescott, J. 2005. Microbiology. $6^{\text {th }}$ ed. Mc Graw Hill Companier. USA.

Murniah. 2005. Pengaruh Lama Penyimpanan Pada Suhu Rendah terhadap Derajat Keasaman dan Angka Reduktase Susu Sapi Pasteurisasi. Skripsi. Fakultas Pertanian. Universitas Islam Kalimantan. Banjarmasin.
Nababan, M., I Ketut Suada, dan I. B. N. Swacita. 2015. Kualitas susu segar pada penyimpanan suhu ruang ditinjau dari uji alkohol, derajat keasaman, dan angka katalase. Indonesia Medicus Veterinus. 4(4): 374--382.

Puspitarini, O. R. dan K. Inggit. 2015. Pengaruh lama simpan pada refrigerator terhadap kualitas susu kambing pasteurisasi. Dinamika Rekasatwa. 8(1): 41--44.

Parakasi, A. 2009. Ilmu Nutrisi dan Makanan Ternak Ruminan. UI Press Jakarta.

Rofi'i, F. 2009. Hubungan Antara Jumlah Total Bakteri dan Angka Katalase terhadap daya Tahan Susu. Fakultas Kedokteran Hewan. Institut Pertanian Bogor. Skripsi. IPB Repository.

Sari, M., Swacita I. B. N., Agustina K. K. 2013. Kualitas susu kambing peranakan etawah post thawing ditinjau dari waktu reduktase dan angka katalase. J Veteriner 2(2): 202-207.

Sarwono, B. 2007. Beternak Kambing Unggul. Jakarta: Penebar Swadaya.

Sawitri, E. 2006. Macam-macam Olahan Susu. Penebar Swadaya. Jakarta.

Setya, A. W. 2012. Teknologi Pengolahan Susu. Fakultas Teknologi Pertanian Universitas Slamet Riyadi. Surakarta.

Sudarwanto, M. 2012. Pemeriksaan Susu dan Produk Olahannya. IPB Press. Bogor.

Susilorini, T. E. dan M. E. Sawitri. 2006. Produk Olahan Susu. Penebar Swadaya. Jakarta.

Suwito, Widodo. 2010. Bakteri yang sering mencemari susu: deteksi, patogenesis, epidemologi, dan cara pengendaliannya. J. Litbang Pertanian 29(3): 96--100.

Soeparno, Indratiningsih, S. Triatmojo, dan Rihastuti. 2001. Dasar Teknologi Hasil Ternak. Universitas Gajah Mada, Yogyakarta.

Umar, Razali, dan A. Novita. 2014. Derajat keasaman dan angka reduktase susu sapi pasteurisasi dengan lama penyimpanan yang berbeda. J. Medika Veterinaria. 8(1): 43--46). 